\title{
Christian Angelet, Une romancière de chez nous en Flandre: Nicole Verschoore
}

Jean-Paul De Nola

\section{(2) OpenEdition}

1 Journals

\section{Édition électronique}

URL : http://journals.openedition.org/studifrancesi/4479

DOI : 10.4000/studifrancesi.4479

ISSN : 2427-5856

Éditeur

Rosenberg \& Sellier

\section{Édition imprimée}

Date de publication : 1 septembre 2016

Pagination : 367-368

ISSN : 0039-2944

\section{Référence électronique}

Jean-Paul De Nola, "Christian Angelet, Une romancière de chez nous en Flandre: Nicole Verschoore», Studi Francesi [En ligne], 179 (LX | II) | 2016, mis en ligne le 01 septembre 2016, consulté le 18 septembre 2020. URL : http://journals.openedition.org/studifrancesi/4479 ; DOI : https://doi.org/ 10.4000/studifrancesi.4479

Ce document a été généré automatiquement le 18 septembre 2020.

\section{(c) $($ ) $\odot$}

Studi Francesi è distribuita con Licenza Creative Commons Attribuzione - Non commerciale - Non opere derivate 4.0 Internazionale. 
Christian Angelet, Une romancière de chez nous en Flandre: Nicole Verschoore

Jean-Paul De Nola 


\section{RÉFÉRENCE}

CHRISTIAN ANGELET, Une romancière de chez nous en Flandre: Nicole Verschoore, «Nord. Revue de critique et de création littéraires du Nord/Pas-de-Calais» 65, juin 2015, pp. 119-130.

1 Mme Verschoore appartient à cette bourgeoisie flamande, plus précisément gantoise qui, non oublieuse de son passé sous la couronne française, n'a jamais cessé de s'exprimer, par la voix et par la plume, dans la langue qui nous est chère. Journaliste, historienne, philologue germaniste et surtout romancière, elle a suscité l'intérêt du professeur Angelet. Celui-ci a distingué dans l'évolution littéraire de Nicole Verschoore deux grands blocs d'écriture. Le premier, qui comprend Le Maître du bourg (roman, 1994) et la trilogie romanesque La Passion et les hommes (2004-2007), évoque la vie des ancêtres de l'auteure (un bourgmestre de la ville de Bruxelles, et puis toute une famille gantoise, père, fils et petit-fils), tout cela greffé sur l'histoire de la Belgique, depuis la révolution de 1830 jusqu'au conflit scolaire qui opposa cléricaux et libéraux.

2 La seconde époque de l'évolution littéraire de Nicole Verschoore comprend, nous précise M. Angelet, «des navettes entre la fiction et la réalité». C'est ce que nous découvrirons dans les nouvelles, au contenu à moitié autobiographique, à moitié inventé, qui portent le titre Vivre avant tout! (2006). La dernière nouvelle de ce volume donne lieu à un développement intitulé Ainsi donc, une fois encore (2013). Mais entretemps Nicole Verschoore avait encore produit un roman, L'Énigme Molo (2009), un ouvrage de mélanges littéraires, Autobiographie d'un siècle (2010) et un autre roman, Les Inassouvis (2013). Laissons pour la bonne bouche les douze nouvelles de L'Innocence en Italie (2014) où Nicole Verschoore, encore trop peu connue en-deçà des Alpes, évoque des paysages et des personnages de Capri et d'ailleurs. 